\title{
INTERNAL CONSEQUENCES OF INTERNATIONAL AIR REGULATIONS
}

\author{
Erwin Seago and Victor E. Furman*
}

$\mathrm{T}$ HE International Civil Aviation Conference which convened last November in Chicago was the direct result of an awakening among the nations of the world to the dangerous prospect of greatly expanded international air navigation in a postwar world lacking in uniform air-traffic rules and providing no adequate political or legal foundation for global flight. The pre-war stature of international aviation already had begun to focus attention upon the fact that while, technologically, we fly, widely and well, legally, and politically we remain grounded in the past. The Chicago conference was a joint effort by fifty-four nations of the world ${ }^{x}$ to create a framework of international law and politics within which postwar civil aviation can realize its full potentialities.

The attempt on the international level to conform aerial-navigation standards to a reasonable and safe international pattern may have indirect consequences not fully contemplated. As Mr. Justice Holmes said in Missouri v. Holland," there may have been "called into life a being the development of which could not have been foreseen completely by the most gifted of its begetters." These words were spoken with reference to the United States Constitution, but it is our opinion that they will prove prophetic in application to the Chicago Convention-the "constitution" of the International Civil Aviation Organization. This opinion is based on this study and on personal observation of and participation in the Chicago Conference. The ratification of the Convention by the United States will have a profound, but generally unpremeditated, influence on domestic aviation, in that it promises to eliminate our state lines with respect to many air-traffic rules and regulations.

* Of the Chicago Bar.

Ifghanistan, Australia, Belgium, Bolivia, Brazil, Canada, Chile, China, Colombia, Costa Rica, Cuba, Czechoslovakia, Dominican Republic, Ecuador, Egypt, El Salvador, Ethiopia, France, Greece, Guatemala, Haiti, Honduras, Iceland, India, Iran, Iraq, Ireland, Lebanon, Liberia, Luxembourg, Mexico, Netherlands, New Zealand, Nicaragua, Norway, Panama, Paraguay, Peru, Philippine Commonwealth, Poland, Portugal, Spain, Sweden, Switzerland, Syria, Turkey, Union of South Africa, United Kingdom, United States, Uruguay, Venezuela, and Yugoslavia; and the Danish Minister and the Tai Minister who were invited to the conference by the government of the United States to be present in their personal capacities.

2252 U.S. 4 I6 (I920). 
Full understanding and appreciation of the unique opportunities to foster the development of international civil aviation presented at the Chicago Conference is possible only after a review of the international situation prior to the Conference.

It must first be understood that international aviation exists at present only by concession, not at all by right. The sovereignty of each nation of the globe over its own air space is absolute. The permanent Convention drafted at Chicago recognized and continued this situation. ${ }^{3}$

In the past this sovereign control of the air often has been utilized principally as a means of levying toll upon international flight, or as a method of otherwise exploiting some strategic geographical location or political advantage. ${ }^{4}$ It has been truly said, relative to this type of international bargaining, "In the long record of negotiation, there is little indication of any policy specifically directed to the improvement of aviation services in the general interest, or of any consideration of what would be best for the countries whose territories constituted the arena for so much international wrangling." 5

The attempts of the past to remedy this situation and to standardize air-navigation rules and practices have not been very successful. The $I n$ ternational Convention for the Regulation of Aerial Navigation drafted at Paris on October I3, I9I9, establishing a "Commission International de Navigation Aerienne" (CINA), was the initial step in the field of public air-law conventions. This commission was largely European in character and influence, and although the convention was signed, it was never ratified, by the United States. The technical annexes to that convention now are largely out of date. A somewhat similar international convention, the Ibero-American Convention Relating to Air Navigation (Convenio IberoAmericano de Navigacion Aerea [CIANA]), which was signed at Madrid on November I, I9'26 (never'adhered to by the United States), had only a limited influence and that largely among Spanish-speaking nations. The Habana Convention on Commerical Aviation of February 20 , I928, was ratified by the United States and joined in by many Latin-American countries. It contained no technical provisions. Another convention somewhat of this type, to which the United States was a party, and which had the limited effect of permitting the contracting parties to enforce certain sanitary and

3 Article I of the Convention on International Civil Aviation provides that "the contracting States recognize that every other State has complete and exclusive sovereignty over the airspace above its territory."

4 See VanZandt, Civil Aviation and Peace, for many examples.

5 Brigadier-General Sir Osborne Mance, International Air Transport 98 (r943). 
quarantine regulations upon visiting aircraft, was the International Sanitary Convention for Air Navigation, adopted by the Permanent Committee of the International Public Health Office in Paris on April 29, I932.

In addition to the above public air-law conventions a number of draft conventions in the field of private air-law have been prepared from time to time by the "International Technical Committee of Aerial Legal Experts" (Comité International Technique d'Experts Juridiques Aërriens [CITEJA]), since the organization of this committee on May ${ }_{7} 7$, I926. This was a continuing committee on which some thirty states were represented, including the United States. It prepared draft conventions for consideration and action at diplomatic conferences, to which delegates from the various states were accredited. These conventions embodied rules of law to be applied to foreign aircraft which had been permitted to fly the air space of the contracting parties. ${ }^{6}$ It is expected that efforts along the lines followed by this committee will be continued after the war. ${ }^{7}$

These conventions in the fields of public and private international air law, limited as they have been in influence and outmoded as are their technical provisions, serve today chiefly to direct attention to the urgent need for modern, universal air standards and for an agreement on the

\footnotetext{
6 Examples of this type of private air-law convention are the Warsaw convention of October I2, I929, "for the unification of certain rules relating to international transportation by air," which has been adhered to by the United States, and Rome convention of May 29, I933, "for the unification of certain rules relating to the precautionary attachment of aircraft," which was signed on behalf of the United States. An example of the enforcement of conventions of this type by the courts of the United States is found in Wyman v. Pan American Airways, Inc., 43 N.Y. S. 2 d 420 (r943). In this case recovery was permitted only in accordance with the Warsaw convention. Generally regarding CITEJA see Ide, The History and Accomplishments of the International Technical Committee of Aerial Legal Experts, 3 Journal of Air Law 27 (1932), and Latchford, Codification of Private International Air Law, an address before the Federal Bar Association, Washington, I936.
}

7 Resolution No. VII adopted at the Chicago Conference is as follows:

"I. That the various governments represented at this International Civil Aviation Conference give consideration to the desirability of bringing about the resumption at the earliest possible date of the CITEJA sessions which were suspended because of the outbreak of war; of making necessary contributions toward the expenses of the Secretariat of CITEJA meetings; and

" 2 . That consideration also be given by the various governments to the desirability of coordinating the activities of CITEJA with those of the Provisional International Civil Aviation Organization and, after it shall have come into existence, of the permanent International Civil Aviation Organization established pursuant to the Convention on International Civil Aviation drawn up at Chicago on December 6, 1944.

On the other hand, Article 80 of the permanent Convention states relative to CINA and the Habana convention that "each contracting State undertakes, immediately upon the coming into force of this Convention, to give notice of denunciation of the Convention relating to the Regulation of Aerial Navigation signed at Paris on October I3, Igr9, or the Convention on Commercial Aviation signed at Habana on February 20, I928, if it is a party of either. As between contracting states, this Convention supersedes the Conventions of Paris and Habana previously referred to." 
political level among the nations of the world, which can serve as a firm foundation for the growth of international civil aviation.

It was against this background that the International Civil Aviation Conference convened in Chicago on November I, I944. When the Conference adjourned on December 7 , the following instruments had been formulated:

I. The Final Act, consisting of. twelve "resolutions and recommendations"8 adopted by the Conference. (All other instruments drafted at the Conference are appendices to the Final Act.)

2. The Interim Agreement on International Civil Aviation, designed to "establish a provisional international organization of a technical and advisory nature of sovereign States for the purpose of collaboration in the field of international civil aviation," to "be known as the Provisional International Civil Aviation Organization.",

3. The Convention on International Civil Aviation, representing an agreement "on certain principles and arrangements in order that international civil aviation may be developed in a safe and orderly manner and that international air transport services may be established on the basis of

8 They are listed as follows:

I. Preparation of the Final Act

II. Draft Technical Annexes

III. Technical Personnel

IV. Metric System

V. Transfer of Title to Aircraft

VI. Rome Convention (May 29, 1933) Relating to the Precautionary Attachment of Aircraft

VII. Resumption of and Coordination with the Sessions of CITEJA

VIII. Standard Form of Agreement for Provisional Air Routes

IX. Flight Documents and Forms

X. Recommendation That Certain Matters Be Referred to the Interim Council for Study

XI. Publication of Documentation

XII. Resolution of Gratitude and Appreciation

9 Article I, § I, of the Agreement. The organization established by this Agreement "shall last until a new permanent convention on international civil aviation shall have come into force, or another conference on international civil aviation shall have agreed upon other arrangements; Provided, however, That the interim period shall in no event exceed three years from the coming into force of the present Agreement," Article I, $\$$. The Agreement "shall come into force when it has been accepted by twenty-six states," Article XVII. The purpose of the Interim Agreement was to establish, immediately, a temporary international organization for the period between the Chicago Conference and the permanent International Organization. To insure that the provisional organization shall come into being promptly, Article XVI of the Agreement provides that no state elected at the Chicago Conference to a place on the Interim Council shall become a member of the council until it has accepted the Interim Agreement and "unless such acceptance has taken place within six months after December 7, I944."

Forty-four nations signed the Interim Agreement at Chicago, but at this writing only six, Canada, Ethiopia, the Netherlands, Norway, Poland, and the United States, have adhered to it. The seat of the provisional organization will be at Montreal, Canada. 
equality of opportunity and operated soundly and economically," "ro establishes the permanent International Civil Aviation Organization. This convention, the "constitution" of the permanent organization, is in four parts. ${ }^{11}$ The organization it establishes consists of an assembly of all the contracting states and a permanent council of twenty-one members elected by the assembly every three years. An Air Navigation Commission is provided for as a technical aid to the organization. ${ }^{x_{2}}$ The permanent organization comes into being after twenty-six states have formally ratified it. ${ }^{\mathrm{x}}$

4. The International Air Services Transit Agreement, frequently referred to as the "Two-Freedoms" document, under the terms of which "each contracting State grants to the other contracting States the following freedoms of the air in respect of scheduled international air services:

(I) The privilege to fly across its territory without landing.

(2) The privilege to land for non-traffic purposes. ${ }^{14}$ These are known as the "political" freedoms.

${ }^{20}$ Preamble of the Convention.

x Part I, Air Navigation, with the following chapters:

I. General Principals and Application of the Convention

II. Flight over Territory of Contracting States

III. Nationality of Aircraft

IV. Measures to Facilitate Air Navigation

V. Conditions to Be Fulfilled with Respect to Aircraft

VI. International Standards and Recommended Practices

Part II, The International Civil Aviation Organization, with the following chapters:

VII. The Organization

VIII. The Assembly

IX. The Council

$\mathrm{X}$. The Air Navigation Commission

XI. Personnel

XII. Finance

XIII. Other International Arrangements

Part III, International Air Transport, with the following chapters:

XIV. Information and Reports

XV. Airports and Other Air Navigation Facilities

XVI. Joint Operating Organizations and Pooled Services

Part IV, Final Provisions, with the following chapters: ,

XVII. Other Aeronautical Agreements and Arrangements

XVIII. Disputes and Default

XIX. War

$\mathrm{XX}$. Annexes

XXI. Ratifications, Adherences, Amendments, and Denunciations

XXII. Definitions

There are a total of ninety-six Articles to the Convention.

${ }^{2}$ Article ${ }_{56}$.

${ }^{13}$ Article $9 \mathrm{I}(b)$.

14 Article I, § I. 
5. The International Air Transport Agreement, often called the "FiveFreedoms" document. It includes the two "political" freedoms of the Transit Agreement, and in addition grants contracting states the following "cconomic" freedoms:

(I) "The privilege to put down passengers, mail and cargo taken on in the territory of the State whose nationality the aircraft possesses;

(2) "The privilege to take on passengers, mail and cargo destined for the territory of the State whose nationality the aircraft possesses; and

(3) "The privilege to take on passengers, mail and cargo destined for the territory of any other contracting State and the privilege to put down passengers, mail and cargo coming from any such territory." "rs

These two "freedoms" documents represent a great step forward in freeing international air-transport from the pre-war type of nationalboundary exploitation. At the same time domestic air-transport receives protection in that each contracting state retains its cabotage traffic. ${ }^{16}$

6. The Technical Annexes ${ }^{17}$ forming Appendix V to the Final Act were drafted pursuant to Resolution II adopted by the Chicago Conference. ${ }^{18}$

${ }^{25}$ Article I, § $\mathbf{~ . ~}$

${ }^{36}$ Article I, $\S 4$ of the Transport Agreement provides that "each contracting State shall have the right to refuse permission to the aircraft of other contracting States to take on in its territory passengers, mail and cargo carried for remuneration or hire and destined for another point within its territory." This same language appears as a part of Article 7 , chapter ii of the permanent Convention.

17 Twelve in number, as listed in the text, infra, p. 340 .

${ }^{18}$ Resolution II, Draft Technical Annexes:

WeEREAS: The largest possible degree of international standardization of practice in many matters is important to safe, expeditious, and easy air navigation; and

WhEREAS: These matters typically involve problems of great variety and complexity, and require that much new ground be explored; and

WEEREAS: Considerable progress has been made, during the discussions of the present Conference, in the development of practice agreed upon as proper by the technicians participating in the discussions, but the time has been too limited, and the number of personnel able to participate directly too small, to permit carrying the discussions to final conviction of the adequacy or correctness of certain of the determinations here made;

The International Civil Aviation Conference

REsolves:

That the drafts of annexes for an international civil aviation convention, which are attached hereto as Appendix V, be accepted by the Conference, upon the bases that:

(a) The drafts as now presented shall be accepted by the participating States for immediate and continuing study;

(b) They shall be accepted as constituting models of the desirable scope and arrangement of the several annexes;

(c) The participating States undertake to forward to the Government of the United States (or to the Provisional International Civil Aviation Organization if it shall in the meantime have been established), by May I, I945, any recommendations which they may have for necessary additions, deletions, or amendments;

(d) The Government of the United States (or the Provisional International Civil Aviation Organization) will transmit such suggestions to the other participating States in anticipation 
In the language of Mr. Adolf A. Berle, Jr., president of the Conference, in his closing address, these international rules and regulations are designed to establish "the technical freedom of the air."

The Final Act, containing twelve "resolutions and recommendations," was signed by the representatives of fifty-four nations. ${ }^{9}$ The Interim Agreement at this writing has been signed by forty-four nations, ${ }^{20}$ the permanent Convention by forty-one, ${ }^{2 x}$ the Transit (Two-Freedoms) Agreement by thirty-seven, ${ }^{22}$ and the Transport (Five-Freedoms) Agreement by twenty-four. ${ }^{23}$ That the area of agreement among the nations of the world was so large, on a subject as complex and as important as international aviation, is surprising and certainly encouraging. Lack of complete concurrence on all topics does not detract from the success of the Conference but points rather to the difficulty and scope of the problems presented, to the conflicts of political and economic interests among the nations represented, and finally to the failures and shortcomings of previous attempts at international cooperation and understanding. ${ }^{24}$

of meetings of the technical committees to be established by the Provisional International Civil Aviation Organization for dealing with the subject matter of the various documents, such meetings to be held as soon as practicable thereafter for the purpose of ultimate acceptance of the annexes in final form for attachment to a convention.

(e) Meanwhile, in so far as the Technical Subcommittees have been able to agree on recommended practices, the States of the world, bearing in mind their present international obligations, are urged to accept these practices as ones toward which the national practices of the several States should be directed as far and as rapidly as may prove practicable.

ig See note I, supra.

${ }^{30}$ Afghanistan, Australia, Belgium, Bolivia, Canada, Chile, China, Costa Rica, Dominican Republic, Ecuador, Egypt, Ethiopia, France, Greece, Guatemala, Haiti, Honduras, Iceland, India, Iran, Iraq, Ireland, Lebanon, Liberia, Mexico, Netherlands, New Zealand, Nicaragua, Norway, Peru, Philippine Commonwealth, Poland, Portugal, Spain, Sweden, Switzerland, Syria, Turkey, United Kingdom, United States, Uruguay, Venezuela, Denmark, and Thai.

"x Afghanistan, Australia, Belgium, Bolivia, Canada, Chile, China, Costa Rica, Dominican Republic, Ecuador, Egypt, France, Greece, Guatemala, Haiti, Honduras, Iceland, India, Iran, Iraq, Ireland, Lebanon, Liberia, Mexico, Netherlands, New Zealand, Nicaragua, Norway, Peru, Philippine Commonwealth, Poland, Portugal, Spain, Sweden, Syria, Turkey, United Kingdom, United States, Uruguay, Denmark, and Thai.

22 Afghanistan, Belgium, Bolivia, Canada, Chile, Costa Rica, Ecuador, Egypt, Ethiopia, France, Greece, Guatemala, Haiti, Honduras, Iceland, India, Iran, Iraq, Lebanon, Liberia, Mexico, Netherlands, New Zealand, Nicaragua, Norway, Peru, Philippine Commonwealth, Poland, Spain, Sweden, Turkey, United Kingdom, United States, Uruguay, Venezuela, Denmark, and Thai.

${ }_{23}$ Afghanistan, Bolivia, China, Costa Rica, Dominican Republic, Ecuador, Ethiopia, Guatemala, Haiti, Honduras, Iceland, Lebanon, Liberia, Mexico, Netherlands, Nicaragua, Peru, Sweden, Turkey, United States, Uruguay, Venezuela, Denmark, and Thai.

24 VanZandt well summarizes the accomplishments of the Chicago Conference in Foreign Policy Reports, Vol. XX, No. 23 (February 15, I945), in the following language:

"The Conference reaffirmed the absolute sovereignty of every State over the air above its territory. It recognized the exclusive interest of each country in its own internal air services 
The preparation of the Technical Annexes was one of the most valuable phases of the work done at the Chicago Conference. The Annexes are twelve in number, and cover the following subjects:

Annex $A$, Airways Systems

Annex $B$, Communications Procedures and Systems

Annex $C$, Rules of the Air

Annex $D$, Air Traffic Control Practices

Annex $E$, Standards Governing the Licensing of Operating and Mechanical Personnel

Annex $F$, Log Book Requirements

Annex $G$, Airworthiness Requirements for Civil Aircraft Engaging in International Air Navigation

Annex $H$, Aircraft Registration and Identification Marks

Annex I, Meteorological Protection of International Aeronautics

Aninex $J$, Aeronautical Maps and Charts

Annex $K$, Customs Procedures and Manifests

Amiex $L$, Search and Rescue, and Investigation of Accidents.

The size of the task of preparing these rules of the air is indicated by the fact that in their present form they cover 234 typewritten single-spaced legal-size pages.

The Annexes are intended as "models of the desirable scope and arrangement" of the technical rules and regulations governing global flight, which will be adopted finally by the council of the permanent world organization. They become effective and binding on the nations which are members of the permanent organization only when adopted by two-thirds vote of the council and after submission to the member states. ${ }^{25}$ But while they have

(cabotage). It brought together fifty-four nations in the midst of a global war, to exchange postwar aviation views.

"It established a world-wide basis for uniformity in essential technical matters (the technical annéxes). It liberalized the conditions under which post-war international air transport can develop, at least for a large bloc of the world (the Two- and Five-Freedoms Agreements). Finally, it created a world organization of over fifty nations on a consultative rather than a 'planned economy' level, to assure nondiscrimination, to arbitrate injustices or hardships which the action of any member State might be deemed to cause another, and in general to foster the safe and rapid growth of international civil aviation throughout the world.

"This is perhaps as far as any international air conference can be expected to go until the fundamental economic conflicts which separate sovereign states are more fully resolved."

See also Burden, Chicago Critique, 23 National Aeronautics, No. I, p. I5 (Jan., I945).

${ }^{25}$ Article 90 of the Convention provides that:

(a) The adoption by the Council of the Annexes described in Article 54, subparagraph ( 1 ), shall require the vote of two-thirds of the Council at a meeting called for that purpose and shall then be submitted by the Council to each contracting State. Any such Annex or any amendment of an Annex shall become effective within three months after its submission to the contracting States or at the end of such longer period of time as the Council may prescribe, unless in the meantime a majority of the contracting States register their disapproval with the Council.

(b) The Council shall immediately notify all contracting States of the coming into force of any Annex or amendment thereto. 
no immediate force and effect as international law, their influence already is being felt. The second Resolution adopted as a part of the Final Act at Chicago contemplates this. ${ }^{26}$

After the establishment of the world organization these international technical rules and standards, as finally adopted by the council, will be binding upon the member states, subject to the methods of obtaining compliance specified in the Convention. ${ }^{27}$ We are concerned here, however, not with the application or enforcement of these standards on the international level, but rather with their effect upon the domestic air rules and regulations of the United States. For this purpose, it is assumed that the Annexes as drafted in Chicago are in fact a statement of approximately what the nations of the world will accept at this time in the way of minimum uniform civil aviation rules and practices. It seems a fair assumption that, after the technical experts of fifty-four nations have collaborated in formulating these regulations, they do represent about the best thought and widest agreement possible in the world today.

It must also be assumed that the permanent Convention will be adhered to by the United States and by at least twenty-five other nations of the world. That this study was undertaken at all attests the conviction of the authors, at least, that this particular international compact will become effective and that the United States will ratify it. This is not merely a hope that this will happen nor a belief that it should. This conviction results, rather, from observation of the trend of the Chicago Conference and from a knowledge of the wide approval of its results. It springs also from an appreciation of the fact that the airplane is peculiarly the vehicle of internal relations. "Aviation possesses immense possibilities either for good or evil. It represents both a threat and a promise. It can destroy, as the present war has shown so impressively; but it can also bring fresh hope and opportunity to the world. Whether its destructive or constructive phase will predominate after the war is of great importance to mankind." ${ }_{28}$ The people of the world have learned, too, the truth of these statements: "A nation's transportation system is an integral part of its war-making potential. From the start civil airlines, both domestic and foreign, have played a vital part in the war. Civil transport equipment because of its great flexibility is peculiarly well adapted to military requirements.",29

\footnotetext{
${ }^{26}$ See note 18 , supra.

${ }^{27}$ See Articles 28, 37, 38, 39, 40, 85, 86, 87, and 88.

${ }^{28}$ VanZandt, Civil Aviation and Peace p. iii (I944).

29 Tbid., p. 22.
} 
The type of international understanding expressed in the instruments signed by fifty-four nations at Chicago last December is the best, perhaps the only, assurance that aviation will become, as it certainly can, a great new force for prosperity and peace.

The only type of international agreement mentioned in the United States Constitution is the treaty. ${ }^{30}$ Of the Agreements drafted at Chicago only the permanent Convention has been submitted to the United States Senate..$^{3 \mathrm{x}}$ Of the forty-one nations which signed the permanent Convention only the government of Poland, at this writing, has ratified it.32

The United States, however, has become a party to many international compacts by executive action alone and without Senate concurrence. Throughout most of our national history the Chief Executive has considered himself vested with the power to enter into various forms of international agreements covering a wide range of subjects. In fact, more executive agreements than treaties have been made. ${ }^{33}$

The Interim Agreement and both of the "freedoms" agreements have been adhered to by the United States through executive action only. ${ }^{34}$ However, Article II, section 2, of the Transit Agreement and Article IV, section 3, of the Transport Agreement ${ }^{35}$ become operative only upon ratification of the permanent Convention, and the second paragraph of

${ }^{30}$ The term "treaty" is used in Article $\mathrm{I}, \S$ ro: "No State shall enter into any treaty" in; Article VI, clause 2: "This Constitution and the Laws of the United States which shall be made in Pursuance thereof; and all Treaties made, or which shall be made, under the authority of the United States, shall be the supreme Law of the Land;" in Article III, \& 2: "The judicial Power shall extend to all cases in Law and Equity arising under this Constitution, the Laws of the United States, and Treaties made, or which shall be made, under their Authority;" and in Article II, § 2: "He [the President] shall have Power by and with the Advice and Consent of the Senate to make Treaties, provided two-thirds of the Senators present concur."

3x On March 12, I945, President Roosevelt transmitted the permanent Convention to the Senate for its advice and consent to ratification. The Convention was referred to the Committee on Foreign Relations, and hearings have been held by a subcommittee of that committee. The Convention has not yet been reported out of the committee.

32 Ratification deposited on April 6, I945.

33 See McClure, International Executive Agreements (194I).

${ }^{34}$ On February 8, I945, by acknowledging that the signatures on these agreements by the delegates of the United States constitute acceptance by the government of the United States and "obligations binding upon it," Department of State press release, February 9, I945.

35 These sections are the same and read as follows: "If any disagreement between two or more contracting States relating to the interpretation or application of this Agreement cannot be settled by negotiation, the provisions of Chapter XVIII of the above-mentioned Convention shall be applicable in the same manner as provided therein with reference to any disagreement relating to the interpretation or application of the above-mentioned Convention." 
Article V of the Interim Agreement is subject to "the requirements of the constitutional processes" of the United States. ${ }^{36}$

We are concerned here with the internal, as distinguished from the external, effects of the international agreements. Since the permanent Convention has been submitted to the Senate for action, adherence by the United States will be by treaty. Therefore the type of international agreement we are interested in here is the treaty rather than the executive agreement. It is believed that from a ratification of this Convention as a formal treaty certain internal consequences may follow which possibly could not result from any other form of attempted adherence.

Under Article VI, clause 2, of the United States Constitution, both laws of Congress and treaties have authority as "the supreme law of the land," but with this important distinction: laws of Congress are "supreme" only if made "in pursuance of the Constitution," while treaties are so if made "under the authority of the United States." 37

In Missouri v. Holland the question of the internal consequences of an international treaty was directly before the Court. This case dealt with a kind of flight regulation, not of airplanes but of birds. Migratory birds were protected under Department of Commerce Regulations promulgated pursuant to the Migratory Bird Treaty Act of July 3, rgr8. This federal statute was passed to give effect to the convention of December 8, rgr6, which was a treaty between the United States and Great Britain. The state of Missouri sought to prevent enforcement of these regulations on the ground that the act was an unconstitutional interference with the rights reserved to the states, an invasion of the sovereignty of the state of Missouri.

In rejecting this contention of the state of Missouri, Mr. Justice Holmes referred to Article VI, clause 2, of the Constitution and stated that if the treaty is valid there can be no dispute about the validity of the statute under Article I, Section 8 [of the Constitution] as a necessary and proper means to execute the powers of the Government..... No doubt the great body of private relations usually fall within the control of the State, but a treaty may override its power.

The significance of the Holland case lies in the fact that, as stated in the opinion, "an earlier act of Congress that attempted by itself and not in pursuance of a treaty to regulate the killing of migratory birds within the States had been held bad in the District Court," citing United States v. Shauver ${ }^{38}$ and United States v. McCullagh. ${ }^{39}$ The similar act passed after

${ }^{36}$ This paragraph reads as follows: "The expenses of the organization shall be borne by the member States in proportions to be decided by the Assembly. Funds shall be advanced by each member State to cover the initial expenses of the Organization."

37252 U.S. 4 I6 (1920). $\quad 3^{38} 214$ Fed. I54 (I9I4). $\quad 3922 x$ Fed. 288 (1915). 
the treaty and intended to fulfil the obligations of the treaty, was upheld in the Holland case. In other words, here is an instance where an act of Congress, invalid as an unconstitutional invasion of state sovereignty, became valid when repassed in pursuance of a treaty. In this manner the federal government can, in a measure, "lift itself by its own boot straps"; it can enlarge its internal powers by entering into an international obligation, the discharge of which requires enlarged internal authority..$^{4^{0}}$

The power of the federal government to discharge its treaty obligations, even if in so doing it violates the laws or policies of the states, has been recognized in many cases, of which at least United States v. CurtissWright Export Corp., ${ }^{4 \mathrm{I}}$ United States v. Belmont, ${ }^{42}$ and United States v.

$4^{\circ} \mathrm{A}$ similar case involving the Dominion of Canada and the International Convention for the Regulation of Aerial Navigation is reported in 146 Law Times Rep. 76, Atty. Gen. of Canada v. Atty. Gen. of Ontario (I93r). In this case, on appeal from the Supreme Court of Canada, after reciting the "necessary and proper" clause of the British North American Act (section 132, granting "The Parliament and Government of Canada all powers necessary or proper for performing the obligations of Canada or any province thereof as part of the British Empire towards foreign countries arising under treaties between the Empire and such foreign countries") and noting the obligations of Canada under the Convention, to fulfil which the Parliament of Canada enacted an "Air Board Act," under which detailed air regulations were promulgated, it was held that, as between the Dominion and the Provinces of Canada, "substantially the whole field of legislation in regard to aerial navigation belongs to the Dominion."

${ }^{41} 299$ U.S. 304 (1936). In this case "an indictment was returned in the court below, the first count of which charges that appellees, beginning with the 29th day of May, 1934, conspired to sell in the United States certain arms of war, namely fifteen machine guns to Bolivia, a country then engaged in armed conflict in the Chaco, in violation of the Joint Resolution of Congress approved May 28, x934, and the provisions of a proclamation issued on the same day by the President of the United States pursuant to authority conferred by Section I of the resolution." Among the defenses was that the joint resolution effected an invalid delegation of legislative power to the President. This point was sustained in the court below, but not by the Supreme Court. Mr. Justice Sutherland in the opinion of the Court, stated that "the investment of the federal government with the powers of external sovereignty did not depend upon the affirmative grants of the Constitution. The powers to declare and wage war, to conclude peace, to make treaties, to maintain diplomatic relations with other sovereignties, if they had never been mentioned in the Constitution, would have vested in the federal government as necessary concomitants of nationality. . . . It is important to bear in mind that we are here dealing not alone with an authority vested in the President by an exertion of legislative power, but with such an authority plus the very delicate, plenary and exclusive power of the President as the sole organ of the federal government in the field of international relations - a power which does not require as a basis for its exercise an act of Congress, but which, of course, like every other governmental power, must be exercised in subordination to the applicable provisions of the Constitution. .... In the light of the foregoing observations, it is evident that this court should not be in haste to apply a general rule which will have the effect of condemning legislation like that under review as constituting an unlawful delegation of legislative power."

${ }^{42} 3$ or U.S. 324 ( 1937 ). This is one of the cases which arose out of the Litvinov assignment of certain claims, including a deposit with August Belmont, a New York banker. The assignment and the United States' recognition of the Union of Soviet Socialist Republics as the de jure government of Russia were coincident. The holding of the case was that because of this assignment and recognition of the government of Russia the deposit belonged to the United States regardless of the policies of the state of New York. The language of Mr. Justice Sutherland, 
$P$ ink $^{43}$ should be mentioned as interesting recent expression of the Supreme Court.

While these cases, too, touch upon the delicate and involved question of the status of executive agreements, we need not particularly concern ourselves here with this problem except to note that the powers of Congress to legislate, in order to effectuate a treaty, are much better recognized than its like powers under an executive agreement. It is not at all clear that under the latter type of international arrangement the states have the protection which it was intended they should have under the Constitution. It is one thing to say that the power of the Chief Executive in the international field is extraconstitutional, and quite another to conclude that as a consequence of an executive agreement, Congress acquires any authority above or beyond that delegated to it by the Constitution. ${ }^{44}$

who delivered the majority opinion, is quite broad: "Plainly, the external powers of the United States are to be exercised without regard to State laws or policies . . . . The same rule would result in the case of all international compacts and agreements from the very fact that complete power over international affairs is in the national government and is not and cannot be subject to any curtailment or interference on the part of the several states. In respect of all international negotiations and compacts, and in respect of our foreign relations generally, state lines disappear."

${ }^{43} 3$ I 5 U.S. 203 (1942). This case also arose out of the Litvinov assignment. Here the United States sued to recover the assets of the New York branch of a Russian insurance company. A dismissal of the complaint was reversed. Here again the majority of the Court said (at p. 233) that "there are limitations on the sovereignty of the States. No State can rewrite our foreign policy to conform to its own domestic policies. Power over external affairs is not shared by the States; it is vested in the national government exclusively. It need not be so exercised as to conform to state laws or state policies, whether they be expressed in constitutions, statutes, or judicial decrees. And the policies of the States become wholly irrelevant to judicial inquiry when the United States, acting within its constitutional sphere, seeks enforcement of its foreign policy in the courts." The language of United States v. Belmont, supra, note 42 , was approved. "State law must yield when it is inconsistant with, or impairs the policy or provisions of, a treaty or of an international compact or agreement" (p. 23I), citing Nielsen v. Johnson, 279 U.S. 47 ( $\left(\mathrm{r}_{29}\right)$. "Then, the power of a State to refuse enforcement of rights based on foreign law which runs counter to the public policy of the forum (Griffin v. McCoach, $3^{13}$ U.S. 498 , 506) must give way before the superior Federal policy evidenced by a treaty or international compact or agreement."

${ }_{44}$ See Levitan, Executive Agreements: A Study of the Executive in the Control of the Foreign Relations of the United States, 35 Ill. L. Rev. 365 (r940), particularly the following: "A careful evaluation of the function of the treaty-making power and of executive agreements reveals a fundamental distinction as to their effectiveness. Only international issues of which the domestic counterpart is within the range of Congressional authority can be dealt with satisfactorily by means of executive agreements. Executive agreements can be domestically validated as long as they deal with subjects within the legislative competence of Congress, for then Congress assures internal enforcement of the agreement. It must be remembered, however, that this is a federal state and that Congress has but limited authority. Many of the international problems are on the internal level beyond the competence of Congress to legislate; those problems can be dealt with only by treaty. The writer has shown elsewhere that any international question is a proper subject for a treaty. A treaty duly ratified is the supreme law of the land. Congress under the coefficient clause-the necessary and proper clause-can pass legislation necessary to carry out the treaty provisions. This is the basic significance of 
- It therefore appears that the ratification of the Chicago Convention as a formal treaty may have force and effect internally, quite apart.from its international consequences. This is so because under the terms of this Convention, the United States assumes certain obligations actively to participate in the standardization of aerial-navigation practices and procedures on a world-wide basis, and because, to discharge these obligations, federal legislation on the domestic level may be necessary. To the extent necessary to the fulfilment of the obligations of the United States under the Convention, the powers of Congress derive from the treaty. Air rules and regulations adopted in pursuance of the Convention may be sustained even though, but for the Convention, they would be an unconstitutional invasion of State rights. The powers of the federal government to regulate aerial navigation need no longer be limited to those necessary to the protection of interstate or foreign commerce. ${ }^{45}$ To the extent to which the Convention requires, State lines will disappear.

The particular effects which the ratification of the Chicago Convention may have on domestic air rules and regulations depend upon the terms of this. Convention, for acts of Congress made in pursuance of the Convention will be valid only as they serve to discharge our national obligations thereunder. In so far as air rules and regulations are concerned, the purpose of the Convention is to establish a world-wide minimum standard. This intent is clear from Resolution II of the final act signed at Chicago. ${ }^{46}$

In the Convention itself there are many provisions aimed at securing this uniformity in air rules and practices. Under Article r2:

Missouri v. Holland, and it is this that guarantees the continued importance of the treatymaking power."'See also note in 42 Col. L. Rev. 83 I at 842 (I942): "There is another objection to superseding the treaty power, in addition to the question of whether it evades the Constitution. The President and Congress by agreement with some foreign nation, which may be small and insignificant, can destroy states' rights. Although the same holds true for the treaty power, by requiring two-thirds of the Senate to approve, the states are better protected, first from the political party in power and secondly from the larger states overpowering the smaller."

See also Corwin, The Constitution and World Organization (1944). For further comment on the Curtiss-Wright case see Patterson, In re the United States v. the Curtiss-Wright Corporation, 22 Texas L. Rev. 286 and 445 (r944), and Quarles, The Federal Government: As to Foreign Affairs, Are Its Powers Inherent as Distinguished from Delegated? 32 Georgetown L. J. 375 (I944).

'45 The constitutional authority for the Civil Aeronautics Act of 1938 is found in the commerce clause. Rosenhan v. United States I $_{3}$ F. 2d $93^{2}$ (I942), and United States v. Drumm, 55 F. Supp. I5I (1944); and see Fagg, Legal Basis of the Civil Air Regulations, ro Journal of Air Law 7 (I939), and Shadle, Who Controls the Air, 36 Flying 29 (I945). See Binzer, Civil Aviation-the Relative Scope of Jurisdiction of the State and Federal Government, 33 Ken.L. J. 276 (I945), Ryan, Economic Regulation of Air Commerce by the States, 3 I Va. L. Rev. 479 (xg45). See also sections 60.30, and 60.3r of the Civil Air Regulations.

${ }^{46}$ See note 18 , supr: 
Each contracting State undertakes to keep its oren regulations in these respects [rules and regulations relating to flight and maneuver of aircraft] uniform, to the greatest possible extent, with those established from time to time under this Conventiont.47

Article 22 of the Convention expresses the agreement of each contracting state "to adopt all practical measures, through the issuance of special regulations or otherwise, to facilitate and expedite navigation by aircraft between the territories of contracting States." Article 28 states:

Each contracting State undertakes, so far as it may find practicable to:

(a) Provide, in its territory, airports, radio services, meteorological services and other air navigation facilities to facilitate international air navigation, in accordance with the slandards and practices recommended or established from time to time, pursuant to this Convention;

(b) Adopt and put into operation the appropriate standard systems of communications procedure, codes, markings, signals, lighting and other operational practices and rules which may be recommended or established from time to time, pursuant to this Convention;

(c) Collaborate in international measures to secure the publication of aeronautical maps and charts in accordance with standards which may be recommended or established from time to time, pursuant, to this Convention.

Article 33 provides that

certificates of airworthiness and certificates of competency and licenses issued or rendered valid by the contracting State in which the aircraft is registered, shall be recognized as valid by the other contracting States, provided that the requiremenis under which such certificates or licenses were issued or rendered valid are equal to or above the minimum standards which may be established from time to time pursuant to this Convention.

Article 37 expresses a direct undertaking by each contracting State "to collaborate in securing the highest practicable degree of uniformity in regulations, standards, procedures, and organization in relation to aircraft, personnel, airways and auxiliary services in all matters in which such uniformity will facilitate and improve air navigation." Under the provisions of Article 38 any state which finds it impracticable to comply in all respects with the international standard or procedure or to bring its own regulations or practices into full accord with any international standard or procedure, shall give immediate notification to the international organization of the differences between its own practice and that established by the international standard. Under Article 39 any aircraft or part thereof with respect to which there exists an international standard of airworthiness or performance and which fails to satisfy that standard, shall have indorsed on its certificate an enumeration of the details in respect to which it so fails, and any license which does not conform to the international standard

47 Emphasis throughout is ours. 
shall bear an indorsement of all its deficiencies. Article 40 contains the penalty for failing to meet the international standard. This article provides that

no aircraft or personnel having certificates or licenses so endorsed shall participate in international navigution, excepl with the permission of the. State or States whose territory is entered. The registration or use of any such aircraft, or of any certificated aircraft part, in any State other than that in which it was originally certificated shall be at the discretion of the Siate into which the aircraft or part is imported.

Among the objectives of the International Civil Aviation Organization are to "insure the safe and orderly growth of international civil aviation throughout the world," and "meet the needs of the peoples of the world for safe, regular, efficient, and economical air transport." Among the mandatory functions of the council are these: to "adopt in accordance with the provisions of Chapter VI of this Convention, international standards and recommended practices; for convenience designate them as Annexes to this Convention; notify all contracting States of the action taken; consider recommendations of the Air Navigation Commission for amendment of the Annexes and take action in accordance with the provisions of Chapter XX."

Under Article 82 of the Convention all contracting states "accept the Convention as abrogating all obligations and understandings between them which are inconsistent with its terms and undertake not to enter into any such obligations and understandings."

Chapter xviii of the Convention relates to disputes among the contracting states and provides procedure for arbitration and appeal. Article 87 , a part of this chapter, prescribes the penalty for nonconformity by an airline, and Article 88 the penalty for nonconformity by a contracting state. Under Article 87 each contracting state undertakes not to allow the operation of an airline of a contracting state through the air space above its territory if the council has decided that the airline concerned is not conforming to a final decision rendered in accordance with the previous article. Article 88 provides that the assembly shall suspend the voting power in the assembly and in the council of any contracting state that is foind in default under the provisions of this chapter.

Under Article 90 (chapter $\mathrm{xx}$ ) the Annexes, as adopted by the council, become effective unless affirmative action is taken by a majority of the contracting states to register their disapproval with the council.

The cumulative effect of the foregoing provisions of the Convention is sufficient, it is believed, to warrant the statement that, if the United States ratifies this Convention, it will have assumed positive duties and 
will be obligated to take affirmative steps to bring its domestic air rules and regulations into conformity with international minimum standards which will be established by the world organization. To fail to do this would violate not only some of the express language of the Convention but also its plain meaning and intent, and would thwart one of the principal purposes of the world organization.

While the Technical Annexes, in their present form, will not at once, of course, supplant the Civil Air Regulations, they do disclose the present trend of world thought and the area of world agreement on the matters they cover. The United States doubtless will present suggestions for change, and so will many other interested nations. Hearings recently were held in Washington under the supervision of the Civil Aeronautics Administration, at which representatives of American aviation interests of many kinds studied the suggested drafts of the Annexes, and proposed some changes: Out of such discussions in this and many other countries technical air rules and regulations will be evolved which are practicable and safe internationally and to which most of the nations can conform their national practices.

Too, the CAR are constantly being revised and modernized. ${ }^{8} \mathrm{In}$ view of the international standard which the Annexes will embody, and the obligations of the United States to conform to this standard, it is fair to assume that in future modifications of the CAR the Annexes will have considerable influence.

It should be noted, too, that as a practical matter it will be difficult for any air-minded country to resist the trend toward international uniformity, even if it were foolish enough to wish to. In the United States we have seen that the air rules and regulations promulgated by the States tend to approach the federal standards. ${ }^{49}$ This is entirely aside from any compulsion exercised by the federal government, and aside from any superiority inherent in the federal rules and regulations. Doubtless this tendency toward standardization on the higher over-all level will be a practical aid in conforming domestic air rules and regulations to the international standard.

${ }_{4}^{8}$ For instance, as reported in 36 Flying, in February, 1945, the National Association of State Aeronautical Officials has recently offered a model uniform act for state aeronautical departments. "The words 'cooperate' and 'coordination' appear throughout the model act when referring to Federal-State activities. Under the model uniform act, the states could establish safety rules provided they present no conflict with existing Federal Regulations." See also West, Let's Get Practical, 23 National Aeronautics, no. 4 (April, 1945).

${ }^{49}$ Relative to two new aeronautics acts now under consideration (the Lea and the McCarran bills) see Plaine, Air Code Changes, a Comparison of the Civil Aeronautics Act and Proposed Revisions, 23 National Aeronautics, no. 4, p. 18 (April, r945). 
A counterpart comparison of the present provisions of the Annexes and the CAR, as they exist at the moment, probably is not justified, at this time and place. Nevertheless some general observations relative to the similarities and differences which a comparison of these two sets of rules and regulations discloses are thought to be of value.

While there are many differences between the drafts of the Technical Annexes and the Civil Air Regulations of the United States, a study of the two does indicate many similarities, disclosing that wherever possible the Civil Air Regulations were used as the basis for the preparation of the Annexes. For instance, Annex C, Rules of the Air, is primarily based on Civil Air Regulation, Part 6o, Air Traffic Rules; the Annex provisions rela-

' tive to the certification of student pilots, private pilots, and commercial pilots are based on, and differ only in minor detail from, Civil Air Regulation, Part 20, dealing with the same subject matter; the Annex provisions with respect to aircraft dispatcher certificate is practically identical with Civil Air Regulation, Part 24, covering the same type of certificate; and the Annex provisions with respect to physical standards for airmen are in all respects identical with Civil Air Regulation, Part 29.

Whenever differences appear between the Annexes and the Civil Air Regulations, it can usually be said that the minimum requirements prepared at the Chicago Convention have been generalized for international workability, and are accordingly much less detailed than the Civil Air Regulations. Yet, in a comparison of the provisions of the Annex dealing with airline transport, pilot certificates with the corresponding Civil Air Regulations, which are in Part 2x, the requirements of Part 2I appear less stringent. This is necessary, owing to the greater scope and range of international air navigation. Some variations result, too, from the fact that many of the Annexes reflect American technical knowledge and experience even more recent than that presently contained in the Civil Air Regulations.

Among the provisions of the Annexes which are not suitable for comparison here is Annex G, Airworthiness Requirements for Civil Aircraft Engaging in International Air Navigation. This Annex deals in general with requirements for airplane airworthiness, engine airworthiness, propeller airworthiness, and equipment airworthiness. Comparable provisions of the CAR are found in Parts $0_{4}, \mathrm{r}_{3}$, and $\mathrm{r}_{4}$. The comparison of these provisions should be undertaken only by qualified aeronautical engineers. A very exhaustive and interesting paper was delivered on this general subject last January before the War Engineering-Annual Meeting of the Sosiety of Automotive Engineers, by Edward Warner, vice-chairman of the 
Civil Aeronautics Board. For our purposes here we believe it will suffice to quote the following from this paper:

When a group of engineers set to work five months ago on the preparation of a first draft of a possible code of airworthiness requirements for international use, the obstacles to any partial treatment, concentrating upon a few high spots of special significance, appeared so compelling that they substantially abandoned the attempt to define any such limit for their work. They concluded by preparing a draft which was with relatively few exceptions.... co-extensive with the existing American code as set forth in Part $0_{4}$ of the Civil Air Regulations as adopted by the Civil Aeronautics Board. In many respects-though not by any means in all--it was identical with the American requirements currently in force.

For further technical comments with respect to this Annex G, see article by Franklin D. Walker in Flying for June, $1945^{50}$

Hearings are presently being held in the United States, and possibly elsewhere, for the purpose of preparing proposed amendments to many of the Annexes. Even though the Annexes as finally adopted by the council of the International Civil Aviation Organization may differ from the original draft, it is believed the differences will not be fundamental. Their force and effect for the purposes of this article are expected to be about the same.

In conclusion, we believe that the time has arrived when air rules and regulations must be standardized, not only on the national, but also on the international, level. In due course the air regulations set forth in the Annexes of the International Civil Aviation Convention will become the international standard and the minimum national standards for the member nations. We believe and hope that the Chicago Convention will be ratified by the United States, and that such ratification will take the form of a treaty. Congress will thereby be empowered to take all steps necessary to conform national flight practices and procedures to the international standard.

The consequences of this are all to the good. We see no valid fundamental objection to the elimination of state lines, insofar as most air rules and regulations are concerned. National uniformity in such matters will avoid much confusion and uncertainty, materially encourage private aviation, foster intrastate, interstate, and international air transport, and fulfil some of the obligations of this country to promote international good will and peace.

so Vol. 36 , no. 6 . 